\title{
Correction to: Seismic site effects in the Red Zone of Amatrice hill detected via the mutual sustainment of experimental and computational approaches
}

\author{
Gerardo Grelle $^{1}$. Elisa Gargini ${ }^{2} \cdot$ Johann Facciorusso $^{3} \cdot$ Rosalba Maresca $^{4}$. \\ Claudia Madiai ${ }^{3}$
}

Published online: 7 February 2020

(c) Springer Nature B.V. 2020

\section{Correction to: Bulletin of Earthquake Engineering https://doi.org/10.1007/s10518-019-00777-z}

This erratum is published as author names were reversed and should be read as:

Gerardo Grelle

Elisa Gargini

Johann Facciorusso

Rosalba Maresca

Claudia Madiai

The original article has thus been updated with the corrections.

Publisher's Note Springer Nature remains neutral with regard to jurisdictional claims in published maps and institutional affiliations.

The original article can be found online at https://doi.org/10.1007/s10518-019-00777-z.

Gerardo Grelle

gerardo.grelle@uniroma1.it

1 DICEA - Department of Civil, Constructional and Environmental Engineering, Sapienza University of Rome, Rome, Italy

2 Civil Protection Centre, University of Florence, Florence, Italy

3 DICEA - Department of Civil and Environmental Engineering, University of Florence, Florence, Italy

4 DST - Department of Sciences and Technologies, University of Sannio, Benevento, Italy 